\title{
IMPLEMTASI KUALITAS PELAYANAN PENDEKATAN CARTER DAN PENGARUHNYA TERHADAP KEPUASAN UJKS KOPERASI KARYAWAN 1)
}

\author{
Dani Rohmati \\ Program Studi S1Ekonomi Islam-Fakultas Ekonomi dan Bisnis-Universitas Airlangga \\ Email : daniabdurrochim@gmail.com \\ Sunan Fanani \\ Departemen Ekonomi Syariah-Fakultas Ekonomi dan Bisnis-Universitas Airlangga \\ Email : Sunanfanani@gmail.com
}

\begin{abstract}
:
Employee cooperative is the partner of Palapa Nusantara institution based on service quality that consists of sharia compliance, tangibles, reliability, responsiveness, assurance, and empathy. This study aimed to investigate the effect implementation service quality CARTER approach to the members' satisfaction. The first data used were primary data collected though a survey by using questionnaires. Then, the primary data were supported by the secondary data in form of short interviews in order to obtain the maximal results. The results showed that the dimension of reliability and responsiveness partially have a significant effect on the level of members' satisfaction. However, the dimensions of tangibles, assurance, empathy and the sharia compliance have no significant effect to satisfaction of the members. It means that the first hypothesis in this study is accepted. This study also found that reliability is the most influential service to the customers' satisfaction of employee cooperative of Palapa Nusantara Surabaya.
\end{abstract}

Keywords: Service Quality, CARTER Approach, Members' satisfaction, Palapa nusantara.

\section{I.PENDAHULUAN}

Peraturan Pemerintah mengenai

KUKM nomor 16 tahun 2015 tentang pelaksanaan kegiatan USPPS oleh koperasi adalah sebagai dukungan Pemerintah terhadap perkembangan lembaga kevangan syariah di Indonesia, pasalnya Pemberdayaan koperasi merupakan bagian integral dari pembangunan nasional yang bertujuan mewujudkan masyarakat yang adil dan makmur dalam pembangunan bidang ekonomi secara eksplisit tertuang juga pada UUD 1945 yang menekankan implementasi azas kekeluargaan (pasal 33 ayat 1) dan penyelenggaraan perekonomian nasional berdasarkan atas demokrasi ekonomi
Sehubungan dengan hal tersebut, kebijakan yang berpihak pada koperasi telah menjadi harapan yang berkembang luas ditengah tumbuhnya kesadaran dan perhatian masyarakat terhadap nasib ekonomi rakyat. Oleh karena itu, selain pertumbuhan dan stabilitas ekonomi aspek penting yang menjadi agenda besar dalam proses pembangunan ekonomi hari ini dan kedepan adalah kemandirian ekonomi nasional dan pemerataan pembangunan yang berkeadilan.

Kualitas layanan memberikan dorongan kepada anggota untuk menjalin ikatan yang kuat kepada lembaga, ikatan ini dalam jangka panjang memungkinkan

1) Jurnal ini merupakan bagian dari skripsi dari Dani Rohmati, NIM : 041114169 , yang diuji pada 11 Februari 2016 
Rohmati, et al/Jurnal Ekonomi Syariah Teori dan Terapan Vol. 3 No. 3 Maret 2016: 203-218; IMPLEMTASI KUALITAS PELAYANAN PENDEKATAN CARTER DAN PENGARUHNYA TERHADAP KEPUASAN UJKS KOPERASI KARYAWAN

sebuah lembaga untuk memahami dengan seksama harapan serta kebutuhan anggota. Semakin baik dan memuaskan tingkat layanannya maka akan semakin bermutu usaha tersebut, begitu pula sebaliknya. Salah satu strategi yang akan menunjang keberhasilan bisnis dalam sektor jasa atau adalah berusaha menawarkan jasa dengan kualitas yang tinggi, sedangkan kualitas jasa hal yang mencakup suatu perbandingan antara harapan dan persepsi konsumen terhadap kinerja jasa yang mereka terima. (Parasuraman et. al, 1994).

Kepuasan dan pelayanan anggota adalah suatu keadaan dimana keinginan, harapan, dan kebutuhan anggota dapat dipenuhi. Suatu pelayanan dinilai memuaskan bila pelayanan tersebut dapat memenuhi kebutuhan dan harapan anggpta. Ukuran kepuasan nasabah atas pelayanan yang diberikan tidak hanya ditentukan oleh yang melayani saja, akan tetapi lebih banyak ditentukan oleh pihak yang dilayani dalam hal ini yaitu Unit Jasa Kevangan Syariah Yayasan Palapa Nusantara Surabaya.

dengan adanya kualitas pelayanan pendekatan CARTER meliputi Sharia Compliance, tangibles, reliability, assurance, responsiveness, dan empathy selama ini, apakah telah benar-benar memberikan kepuasan bagi anggota UJKS Palapa Nusantara dari 6 indikator tersebut, manakah yang paling dominan mempengaruhi kepuasan anggota koperasi karyawan Palapa Nusantara Surabaya.

Berdasarkan identifikasi masalah dan batasan masalah yang sebagaimana yang dikemukakan, rumusan masalah pada penelitian ini adalah Apakah kualitas pelayanan pendekatan CARTER mempunyai pengaruh singnifikan terhadap kepuasan anggota Unit Jasa Keuangan Syariah koperasi karyawan Yayasan Palapa Nusantara Surabaya secara simultan dan parsial ?.

Adapun tujuan penelitian ini adalah untuk mengetahui dan menganalisis apakah variable kualitas pelayanan pendekatan CARTER mempunyai pengaruh signifikan terhadap kepuasan anggota UJKS koperasi karyawan Yayasan Palapa Nusantara Surabaya, baik secara parsial maupun simultan.

\section{LANDASAN TEORI}

Menurut Sudarsono (2004:18) Prinsip Operasional koperasi syariah hampir tidak jauh beda dengan Bank Umum Syariah, BPRS, maupun BMT. Koperasi Syariah merupakan salah satu bentuk lembaga kevangan Islam yang berkosentrasi pada pemberdayaan usaha kecil dan mikro. Koperasi Syariah didirikan untuk menjangkau dan memfasilitasi masyarakat kelas bawah. Mereka yang biasanya tidak terjangkau oleh BPR Syariah atau Bank Syariah. Prinsip operasinya didasarkan pada bagi hasil, jual beli dan titipan. Untuk mengembangkan usaha dari koperasi 
syariah, maka para pengurus harus memiliki strategi pencairan dana. Sumber dana dapat diperoleh dari anggota, pijaman atau dana-dana yang bersifat hibah atau sumbangan. Semua jenis dana itu dapat diklasifikasikan sifatnya. Sifat komersil, hibah, atau sumbagan atau sekedar titipan saja.

Menurut Umar (2000) kepuasan konsumen adalah tingkat perasaan konsumen setelah membandingkan dengan harapannya. Seseorang yang jika puas dengan nilai yang diberikan oleh produk atau jasa maka sangat besar kemungkinannya untuk menjadi pelanggan dalam waktu yang lama. Tjiptono (1996) berpendapat bahwa kepuasan adalah respon konsumen terhadap evaluasi yang dirasakan antara harapan sebelumnya (atau norma kinerja lainnya) dan kinerja aktual produk yang dirasakan setelah pemakaiannya.

Dalam prespektif islam, semua kegiatan bisnis hendaknya selaras dengan moralitas dan selaras dengan nilai yang telah digambarkan dalam Al-Qur'an. Walaupun bisnis merupakan pekerjaan yang halal, tetapi perlu diingat bahwa semua kegiatan bisnis tidak dibenarkan ketika sudah keluar dari koridor yang ditentuka Allah

Ada beberapa pendekatan tentang dimensi kualitas pelayanan, antara lain parasuraman et al (1998) dimana terdapat lima dimensi yang dirancang untuk mengukur kualitas pelayanan yang didasarkan pada perbedaan antara nilai harapan dengan nilai kinerja yang dirasakan oleh konsumen yaitu: sharia compliance, responsiveness, Reliability, Assurance, Empathy, dan Tangible. Pendekatan lain yang dapat digunakan adalah pendekatan CARTER model milik Othman dan Owen (2002), pendekatan ini biasanya digunakan untuk mengukur kepuasan konsumen Muslim. Model CARTER ini adalah dasar aturan yang dipakai oleh sebuah perusahaan dalam menjalankan roda usaha. Assurance (jaminan) adalah kemampuan karyawan atas pengetahuan terhadap prosuk secara tepat, kualitas, keramah-ramahan, kesopanan dalam memberikan pelayanan, keterampilan informasi dan kemampuan dalam menanamkan kepercayaan konsumen terhadap perusahaan. Responsiveness (daya tanggap/ kesigapan) adalah suatu respon/ kesigapan karyawan dalam membantu konsumen dan memberikan pelayanan yang cepat dan tanggap. Tangible (kemampuan fisik) adalah suatu bentuk penampilan fisik. Empathy (perhatian) adalah kemampuan perusahaan dalam memberikan perhatian yang bersifat indivisual atau pribadi kepada konsumen. Reliability (keandalan) adalah suatu kemampuan untuk memberikan pelayanan yang dijanjikan dan terpercaya.

\section{METODE PENELITIAN}

Penelitian ini termasuk kategori penelitian explanatif (penelitian penjelasan) 
yaitu penelitian yang berusaha menjelaskan hubungan kausal dan menguji keterkaitan antara variabel-variabel penelitian.

Arikunto (1998: 67) mengemukakan bahwa penelitian survey adalah penelitian yang dilakukan pada populasi besar maupun kecil sehingga ditemukan kejadian-kejadian relatif, distribusi dan hubungan-hubungan antara variabel sosiologis dan psikologis. Berdasarkan pendapat tersebut maka penelitian ini adalah explanotary survey dengan pengumpulan data melaui informasi primer yang berhubungan dengan variabel penelitian, dengan cara mengumpulkan data tersebut dari responden melalui kuesioner.

Proses pengumpulan data dalam penelitian ini dibagi menjadi dua bagian, yaitu :

1. Pengumpulan data primer

a. Observasi dimana peneliti melakukan pengamatan langsung di lapangan.

b. Wawancara, yaitu mengadakan tanya jawab langsung dengan responden atau pihak-pihak terkait.

c. Menyebarkan kuesioner kepada responden berupa daftar pertanyaan yang harus diisi oleh responden. Kuesioner disusun berdasarkan item-item dan metode yang digunakan adalah skala Likert Simulated Rating atau skala likert.

2. Pengumpulan data skunder
Yaitu proses pengumpulan data dengan cara melakukan kegiatan evaluasi terhadap laporan hasil pemeriksaan.

\section{Populasi}

Sebelum melakukan penelitian terlebih dahulu kita harus menentukan populasi yang dijadikan obyek penelitian yang merupakan satuan analisa.

Dalam penelitian ini obyek penelitian adalah anggota UJKS Koperasi karyawan palapa nusantara Surabaya yang berjumlah 35 orang sebagai populasi obyek penelitian. Penelitian ini menggunakan sampel jenuh karena tidak dilakukan pemilihan sampel, berhubung jumlah populasi hanya sedikit hingga semuanya dapat dijadikan responden.

\section{Teknik Analisis Data}

Untuk menguji hipotesis dalam penelitian ini akan digunakan teknik analisis regresi berganda yang distandarisasi (menggunakan analisa jalur/ path analisis) dengan bantuan komputer program SPSS.

\section{Validitas}

Dalam pengujian validitas ini digunakan untuk mengukur seberapa akurat suatu alat tes melakukan fungsi ukurannya. Instrumen dikatakan valid apabila mampu mengukur apa yang diinginkan dan dapat mengungkapkan data dari variabel yang diteliti secara tepat. Validitas menunjukkan sejauh mana alat ukur itu mengukur apa yang diukur. Tinggi rendahnya validitas instrumen menunjukkan 
sejauh mana data terkumpul tidak menyimpang dari gambaran tentang variabel yang diteliti. Dengan menggunakan instrumen validitasnya, otomatis hasil penelitian menjadi valid.Dalam pengujian ini digunakan asumsi bahwa nilai korelasi dengan metode Pearson product moment tinggi maka dikatakan valid. Selain itu jika nilai signifikansi yang ditunjukkan kurang dari nilai à $=0,05$ juga dikatakan valid. (Gujarati :2003)

\section{Reliabilitas}

Dalam pengujian reliabilitas ini digunakan untuk menunjukkan sejauh mana alat pengukur dapat dipercaya atau dapat diandalkan. Pada hasil uji reliabilitas dengan uji statistik Cronbach Alpha diketahui bahwa variabel dikatakan realiabel jika memberikan nilai Cronbach's alpha > 0,6. (Gujarati :2003:301)

\section{Analisa Regresi Berganda}

Analisis regresi berganda (multiple regression) digunakan untuk mengetahui pengaruh variabel bebas (penerapan prinsip syariah dan kualitas pelayanan ) terhadap variabel terikat (kepuasan anggota. (Gujarati, 2003: 129).

\section{Asumsi Klasik}

Evaluasi ini dimaksudkan untuk mengetahui apakah penggunaan model regresi linier berganda (Multiple Liniar Regression). Dalam menganalisis telah memenuhi asumsi klasik. Model Regresi Linier berganda akan lebih tepat digunakan dan menghasilkan perhitungan yang lebih akurat, apabila beberapa asumsi berikut dapat terpenuhi, berikut uji asumsi klasik. (Gujarati, 2004: 93).

\section{Uji Normalitas}

Uji normalitas bertujuan untuk menguji apakah dalam model regresi, variabel terikat dan variabel bebas keduanya mempunyai distribusi normal atau tidak. Model regresi yang baik adalah yang memiliki distribusi data normal atau mendekati normal. Salah satu cara termudah untuk melihat normalitas adalah dengan melihat normal probability plot yang membandingkan distribusi komulatif dari data sesungguhnya dengan distribusi komulatif dari distribusi normal. Distribusi normal akan membentuk suatu garis lurus diagonal dan ploting data akan dibandingkan dengan garis normal. Jika distribusi data adalah normal, maka garis yang menggambarkan data sesungguhnya akan mengikuti garis diagonalnya.

\section{Multikolinieritas}

Uji Multikolinieritas dilakukan guna untuk mengetahui apakah variabel bebas tersebut tidak saling berkolerasi atau ada hubungan linier diantara variabel-variabel bebas dalam model regresi . (Gujarati, 2003: 467).

\section{Uji Heteroskedastisitas}

"Uji Heterokedastisitas bertujuan untuk melihat apakah terdapat ketidaksamaan varians dari residual satu pengamatan ke pengamatan yang lain. Dalam regresi linier diasumsikan bahwa 
varians bersyarat dari $E\left(\varepsilon_{i}^{2}\right)=\operatorname{Var}\left(\varepsilon_{i}\right)=\sigma^{2}$ (homokedastisitas), apabila varians bersyarat $\varepsilon_{i}=\sigma_{i}^{2}$ untuk setiap 1, ini berarti variansnya homogen atau homokedastisitas."Uji Heteroskedastisitas bertujuan untuk menguji apakah model regresi terjadi ketidaksamaan variance dari residual satu pengamatan ke pengamatan lain dimana apabila variance dari residual satu pengamatan ke pengamatan yang tetap maka disebut homoskedastisitas dan apabila berbeda disebut heteroskedastisitas. Model yang baik adalah homoskedastisitas atau tidak terjadi Heteroskedastisitas. Dalam hal ini metode korelasi yang dipergunakan adalah korelasi rank spearman. (Santoso,2002:208)

\section{Koefisien Korelasi (R) dan Koefisien Determinasi Berganda $\left(\mathbf{R}^{2}\right)$}

Perhitungan koefisien korelasi digunakan untuk mengukur tingkat keterkaitan hubungan antara variabel terikat kepuasan anggota (Y) dengan variabel bebas kualitas pelayanan (X) . Jika nilai korelasi tersebut mendekati satu (1) maka dikatakan terjadi hubungan yang kuat searah. Artinya jika variabel independent kualitas pelayanan (X) naik, maka variabel dependent kepuasan anggota (Y) juga akan naik. (Gujarati, 1995: 76)

\section{Uji-t ( Uji Parsial)}

Yaitu menguji kebermaknaan koefisien regresi secara parsial pengaruh variabel kualitas pelayanan pendekatan
Carter (X)terhadap variabel terikat kepuasan anggota (Y). (Gujarati, 2003: 129).

\section{Uji-F (Uji Simultan)}

Yaitu untuk menguji signifikansi atau kebermaknaan koefisien regresi secara serentak dan pengaruhnya teradap variabel terikat .(Sugiyono,2003:97)

\section{IV.PEMBAHASAN}

\section{Analisis Validitas dan Reliabilitas Butir}

\section{Kuesioner}

Reliabilitas menunjukkan konsistensi dan stabilitas dari suatu skor (skala pengukuran). Suatu kuisioner dikatakan reliabel jika jawaban seseorang terhadap pertanyaan-pertanyaan yang ada dalam kuisioner adalah konsisten. Untuk mengukur reliabilitas digunakan nilai cronbach alpha. Berikut ini hasil pengujian reliabilitas pada masing-masing variabel penelitian.

\section{Tabel 1}

Hasil Uji Relibialitas

\begin{tabular}{|l|c|c|c|}
\hline \multicolumn{1}{|c|}{ Variabel Penelitian } & $\begin{array}{c}\text { Croubach } \\
\text { Alpha }\end{array}$ & Kriteria & Keterangan \\
\hline Variabel Penerapan symiah (X1) & 0.839 & 0.06 & Reliabel \\
\hline Variabel Tangibles (X2) & 0.805 & 0.06 & Reliabel \\
\hline Variabel Reliability (X3) & 0.835 & 0.06 & Relisbel \\
\hline Variabel Responsiveness (X4) & 0.812 & 0.06 & Reliabel \\
\hline Variabel Assovance (X5) & 0.783 & 0.06 & Reliabel \\
\hline Variabel Emphaty (X6) & 0.830 & 0.06 & Reliabel \\
\hline
\end{tabular}

Sumber : Hasil Penelitian,2016 (diolah)

\section{Uji multikolinieritas}

$$
\text { Adanya }
$$

multikolinieritas

menyebabkan regresi kurang sempurna, sehingga koefisien regresi akan mempunyai standar deviasi yang besar yang berarti pada koefisien-koefisiennya tidak dapat ditaksirkan dengan mudah. 
Uji Berdasarkan hasil perhitungan yang dilakukan dengan menggunakan program SPSS maka dapat diketahui ada atau tidaknya multikolinieritas antara variabel bebas dengan melihat nilai variance inflation factor (VIF)

Hasil pengujian menunjukkan tidak adanya gejala multikolinieritas sebagaimana terlihat pada masing-masing nilai VIF variable bebas lebih kecil dari 4 (Hines dan Douglas 1991 dalam Syahid Natarsyah, 2000).

Tabel 2

Hasil Nilai Tolerance dan VIF

\begin{tabular}{|c|c|}
\hline Variabel & VIF \\
\hline Penerapan Prinsip Syariah (X1) & 1.177 \\
\hline Tangibles $(X 2)$ & 1.281 \\
\hline Reliability $(X 3)$ & 1.167 \\
\hline Responsiveness $(X 4)$ & 1.439 \\
\hline Assurance $(X 5)$ & 1.435 \\
\hline Emphyy $(X 6)$ & 1.210 \\
\hline
\end{tabular}

Sumber : Hasil Penelitian,2016 (diolah)

\section{Uji heteroskedastisitas}

Uji heteroskedastisitas dapat dilakukan melalui beberapa metode seperti metode grafik, Park, Gleyser, Baclet dan Rank spearman.

Tabel 3

Uji Heteroskedastisitas

\begin{tabular}{|l|c|l|}
\hline \multicolumn{1}{|c|}{ Variabel } & Signifikan & Keterangan \\
\hline Penerapan Prinsip Syariah (X1) & 0.849 & Tidak ada Heteroskedastisitas \\
\hline Tangibles $($ X2) & 0.781 & Tidak ada Heteroskedastisitas \\
\hline Reliability $(X 3)$ & 0.857 & Tidak ada Heteroskedastisitas \\
\hline Responsiveness $(X 4)$ & 0.695 & Tidak ada Heteroskedastisitas \\
\hline Assurance (X5) & 0.697 & Tidak ada Heteroskedastisitas \\
\hline Emphty (X6) & 0.826 & Tidak ada Heteroskedastisitas \\
\hline
\end{tabular}

Sumber : Hasil Penelitian,2016 (diolah)

Hasil analisis variable bebas
menunjukkan nilai signifikansi Rank
Spearman seluruh variable bebas lebih

besar dari 0.05 sehingga dapat sisimpulkan bahwa tidak terdapat korelasi antara residual dengan variable bebas. Analisis tersebut memiliki arti tidak terjadi heteroskedastisitas dalam penelitian ini.

\section{Uji normalitas}

$$
\text { normalitas menyatakan tentang }
$$
kedekatan antara nilai pads kuesioner dan kecenderungan yang terbentuk pada gambar scatter plot pada grafik yang dihasilkan oleh perhitungan dengan bantuan software SPSS dan dari hasil grafik tersebut dapat diketahui bahwa nilai-nilai pada hasil kuisoner tersebut menyebar secara normal mendekati garis kecenderungan normalitas pada nilai data hasil kuesioner tersebut.

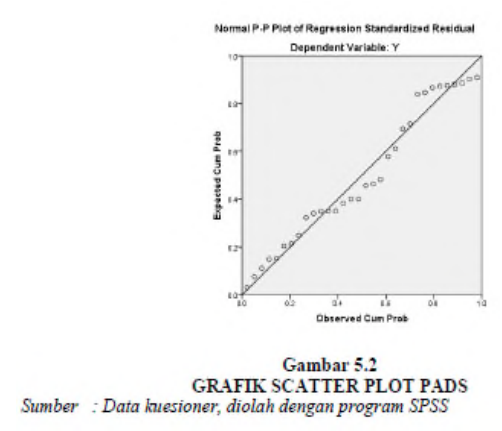

\section{Gambar 1}

GRAFIK SCATTER PLOT PADS

Sumber : Hasil Penelitian,2016 (diolah)

\section{Analisis Koefisien Korelasi ( $R$ ) dan Koefisien Determinasi $\left(\mathbf{R}^{2}\right)$}

KOEFISIEN DETERMINASI SIMULTAN




Sumber : Hasil Penelitian,2016 (diolah)

Nilai R (korelasi berganda) adalah sebesar 0,703. Koefisien tersebut menunjukkan bahwa keeratan hubungan variable bebas dengan variable terikat sebesar $70 \%$. Tanda positif pada koefisien korelasi menandakan bahwa hubungan yang terjadi adalah searah, semakin posotif nila dari variable bebasnya, maka akan semakin mempengaruhi tingkat kepuasan nasabah.

Koefisien determinasi $\left(R^{2}\right)$ dalam penelitian ini menggunakan nilai dari $R$ Square yaitu sebesar 0,373 Koefisien tersebut menunjukkan bahwa pengaruh indikator tangibles, reliability, responsiveness, assurance, emphty dapat mempengaruhii tingkat kepuasan anggota sebesar 37\%, sedangkan sisanya sebesar $63 \%$ dipengaruhi oleh variable lain. Hal ini mengindikasikan bahwa masih terdapat 63\% pengaruh dari variable lain diluar variable bebas yang digunakan dalam penelitian ini.

\section{Analisis Uji t}

Dari table diatas, terdapat dua variable bebas yang besarnya kurang dari 0,05 dan berarti signifikan atau mempunyai pengaruh secara parsial terhadap variable Y. kedua variable tersebut adalah reliability dan responsiveness Hal ini menggambarkan bahwa semakin tinggi kualitas layanan dan penerapan prinsip syariah yang diberikan kepada anggota makan akan semakin tinggi pula tingkat kepuasan nasabah.

Tabel 4

HASIL UJI PARSIAL

\begin{tabular}{|l|r|r|c|}
\hline \multicolumn{1}{|c|}{ Model } & T hitung & Sig. t & Keterangan \\
\hline Variabel Penerapan syæriah (X1) & 0.153 & 0.880 & Tidak Siguifikan \\
\hline Variabel Tangible (X2) & -0.323 & 0.749 & Tidak Signifikan \\
\hline Variabel Reliability (X3) & 3.490 & 0.002 & Siguifikan \\
\hline Variabel Responsiveness (X4) & 2.290 & 0.031 & Siguifikan \\
\hline Variabel Assurance (X5) & 0.580 & 0.567 & Tidal Siguifilan \\
\hline Variable Emphty (X6) & -0.063 & 0.950 & Tidak Siguifilan \\
\hline
\end{tabular}

Sumber : Hasil Penelitian,2016 (diolah)

\section{Analisis Uji F}

\section{Tabel 5}

HASIL UJI SIMULTAN



Sumber : Hasil Penelitian,2016 (diolah)

hasil uji $F$ diatas menunjukkan bahwa hipotesis pertama $\left(\mathrm{H}_{0}\right)$ yang diajukan dala penelitian ini diterima yaitu penerapan prinsip syariah dan kualitas layanan yang diwakili oleh variable tangible, reliability, responsiveness, assurance, dan emphaty secara simultan tidak memiliki pengaruh terhadap kepuasan anggota.

Uji asumsi dasar dan uji penyimpangan asumsi klasik telah dilakukan dalam penelitian ini memberikann hasil tidak ditemukannya data bias sehingga telah memenuhi asumsi BLUE (best linear Unbiased Estimator).Selain itu, dari hasil analisis regresi menunjukkan bahwa dimensi reliability, responsiveness secara parsial 
Rohmati, et al/Jurnal Ekonomi Syariah Teori dan Terapan Vol. 3 No. 3 Maret 2016: 203-218; IMPLEMTASI KUALITAS PELAYANAN PENDEKATAN CARTER DAN PENGARUHNYA TERHADAP KEPUASAN UJKS KOPERASI KARYAWAN

berpengaruh singnifikan terhadap kepuasan nasabah sedangkan dimensi penerapan prinsip syariah, tangibles, assurance, emphty secara parsial tidak berpengaruh singnifikan terhadap kepuasan anggota dan hasil pengolahan ditunjukkan sebagai berikut :

\section{Pengaruh indikator dimensi sharia compliance Terhadap Kepuasan}

Penerapan prinsip syariah merupakan kemampuan mengikuti hukum syariah Islam serta memberikan edukasi kepada anggota pada suatu lembaga, yang dimaksud hukum Islam adalah Al-Qur'an dan Al-Hadist yang merupakan pedoman bagi umat Islam.

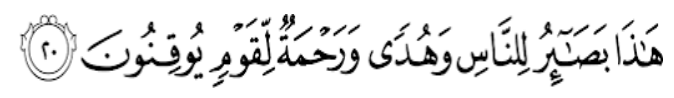

hādzā bashā-iru lilnnāsi wahudan warahmatun liqawmin yuuqinūna

Artinya : "Al Quran ini adalah pedoman bagi manusia, petunjuk dan rahmat bagi kaum yang meyakini."

Nilai sig- $\dagger$ penerapan prinsip syariah sebesar 0,321 < 0.05, menunjukkan bahwa variabel penerapan prinsip syariah tidak berpengaruh secara signifikan terhadap kepuasan anggota koperasi karyawan unit jasa keuangan syariah yayasan palapa nusantara. Hasil penelitian menunjukkan bahwa penerapan prinsip syariah oleh koperasi karyawan yayasan palapa nusantara tidak terlalu mempengaruhi kepuasan anggota, hal ini dapat dilihat dari hasil uji $\dagger$ hitung. Salah satu faktor yang menjadi kemungkinan menyebabkan variabel penerapan prinsip syariah tidak berpengaruh pada kepuasan anggota yaitu adanya beberapa produk yang belum diterapkan secara utuh sehingga hal ini dapat mempengaruhi kualitas layanan atas penerapan prinsip syariah untuk anggota koperasi karyawan. Dalam koperasi karyawan ini.

\section{Pengaruh indikator Tangibles Terhadap Kepuasan}

Menurut Lupiyoyadi (2008:182) tangibles merupakan kemampuan suatu perusahaan untuk menunjukkan eksistensi kepada pihak eksternal yang meliputi fasiitas fisik (gedung, ruang tunggu, gudang, dan lain sebagainya), perlengkapan dan peralatan yang dipergunakan (teknologi), serta penampilan karyawannya. Sedangkan menurut Tjiptono (2001:26) bukti fisik dari jasa, dan berupa fisik gedung, peralatan yang dipergunakan karyawana, dan sarana komunikasi.

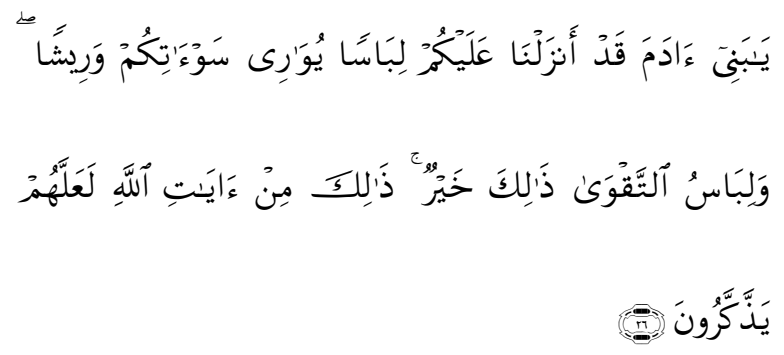

yā banii ādama qad anzalnā 'alaykum libāsan yuwāarii saw-aatikum wariisyan walibāsu alttaqwā dzālika khayrun dzālika min āyaati allāhi la'allahum yadzdzakkarūna

Artinya : "Hai anak Adam, sesungguhnya Kami telah menurunkan kepadamu pakaian untuk menutup auratmu dan pakaian indah untuk 
perhiasan. Dan pakaian takwa itulah yang paling baik. Yang demikian itu adalah sebahagian dari tanda-tanda kekuasaan Allah, mudah-mudahan mereka selalu ingat."

Nilai sig- † tangibles sebesar 0,967 >

0.05, menunjukkan bahwa variabel tangibles tidak berpengaruh secara signifikan terhadap kepuasan anggota koperasi karyawan unit jasa keuangan syariah yayasan palapa nusantara.

Maka dari pihak yayasan palapa nusanara perlu meningkatkan pelayanan pada variabel-variabel yang menurut penilaian nasabah belum sesuai dengan yang diharapkan oleh nasabah.

\section{Pengaruh indikator Reliabitity Terhadap Kepuasan}

Keandalan dalam Lupiyoadi (2008:182) adalah kemampuan perusaaan untuk memberikan layanan sesuai yang dijanjikan secara akurat dan terpercaya. Kinerja harus sesuai dengan harapan pelanggan yang berarti ketepatan waktu, sikap yang simpatik, dan dengan akurasi yang tinggi. Sedangkan Tjiptono (2001:206) mengartikan keanda;an sebagai kemampuan memberikan pelayanan yang dijanjikan dengan segera, akurat dan memuaskan. Dalam Al-Qur'an surat An-Nahl ayat 91, yaitu :

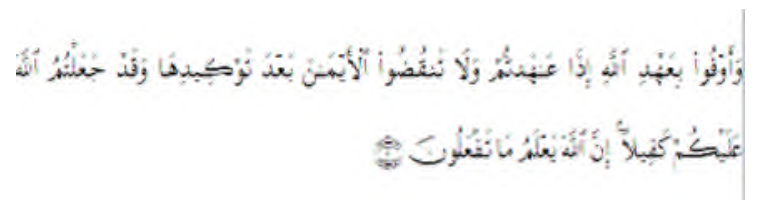

wa-awfuu bi'ahdi allaahi idzā 'āhadtum walā tanqudhū al-aymāna ba'da tawkiidihā waqad ja'altumu allāha 'alaykum kafiilan inna allāha ya'lamu mā taf'alūna.

Artinya: "Dan tepatilah perjanjian dengan Allah apabila kamu berjanji dan janganlah kamu membatalkan sumpah-sumpah(mu) itu, sesudah meneguhkannya, sedang kamu telah menjadikan Allah sebagai saksimu (terhadap sumpah-sumpahmu itu). Sesungguhnya Allah mengetahui apa yang kamu perbuat."

Ayat diatas menjelaskan bahwa setiap manusia diwajibkan menepati janji yang telah ditetapkan. Demikian juga dengan pelaku lembaga keuangan syariah, wajib menepati janji baik yang ditetapkan secara langsung maupun janji-janji dalam bentuk promosi.

Nilai sig- $\dagger$ reliability sebesar 0,002 < 0.05, menunjukkan bahwa variabel reliability berpengaruh secara signifikan terhadap kepuasan anggota koperasi karyawan unit jasa kevangan syariah yayasan palapa nusantara.

\section{Pengaruh indikator Responsiveness Terhadap Kepuasan}

Menurut Lupiyoyadi (2008:182) daya tanggap adalah "suatu kemauan untuk membantu dan memberikan layanan yang cepat (responsive) dan tepat kepada pelanggan, dengan menyampaikan informasi dengan jelas. Sedanglan menurut tjiptono (200:26) daya tanggap adalah keinginan para karyawan untuk membantu para pelanggan dan memberikan layanan dengan cepat dan tepat. 
Rohmati, et al/Jurnal Ekonomi Syariah Teori dan Terapan Vol. 3 No. 3 Maret 2016: 203-218; IMPLEMTASI KUALITAS PELAYANAN PENDEKATAN CARTER DAN PENGARUHNYA TERHADAP KEPUASAN UJKS KOPERASI KARYAWAN

Dimensi responsiveness (daya tanggap) adalah dimensi suatu perusahaan memiliki kemauan untuk memberikan layanan dengan cepat dan tepat guna menunjukkan peilaku bisnis yang profesional. Gunara dan hardiono (2006:115) dalam Transtrianingzah (2006) menjelaskan bahwa pemanfaatan waktu secara efektif benar-benar menjadi hal yang penting. Hasil peneltian dimensi responsiveness menunjukkan bahwa Nilai sig- $\dagger$ sebesar $0,031<0.05$, menunjukkan bahwa variabel responsiveness berpengaruh secara signifikan terhadap kepuasan anggota koperasi karyawan unit jasa keuangan syariah yayasan palapa nusantara. Hal ini sesuai dengan ayat yang di jelaska Al-Qur'an bahwasanya Islam menganjurkan setiap prilaku bisnis untuk bersikap profesional sehingga tidak menyianyiakan amanah yang menjadi tanggung jawabnya, Allah Ta'alā melarang setiap muslim untuk berbuat zalim dalam berserikat/berbisnis sebagaimana termaktub dalam Qs. Şaad (38):24 :

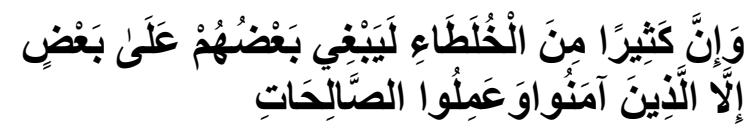

...Wa inna katsira'm-min'al-khulațā-i liyab-gī ba'duhum 'alā ba' $\underline{d}$, ilā'l-lażīna āmanū wa- 'amilu'ś-śalihāti...

Artinya:"...dan sesungguhnya kebanyakan dari orang-orang yang berserikat itu sebahagian dari mereka berbuat zalim kepada yang lain, kecuali orang-orang yang beriman dan berbuat kebajikan..."

\section{Pengaruh indikator Assurance Terhadap Kepuasan}

Definisi jaminan dalam Lupiyoyadi (2008:182) yaitu "pengetahuan, kesopansantunan, dan kemampuan para karyawan perusahaan untuk menumbuhkan rasa percaya pada para pelanggan perusaaan. Baik buruknya prilaku bisnis para pengusaha menentukan sukses dan gagalnya bisnis yang dijalankan. Al- Qur'an Surat Ali Imran ayat 159 menjelaskan :

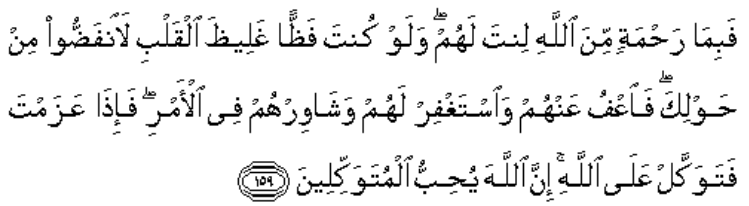

fabimā rahmatin mina allāhi linta lahum walaw kunta fazhzhan ghaliizha alqalbi lainfadhdhū min hawlika fau'fu 'anhum waistaghfir lahum wasyāwirhum fii alamri fa-idzā 'azamta fatawakkal 'alā allāhi inna allāha yuhibbu almutawakkiliina

Artinya : "Maka disebabkan rahmat dari Allah-lah kamu berlaku lemah lembut terhadap mereka. Sekiranya kamu bersikap keras lagi berhati kasar, tentulah mereka menjauhkan diri dari sekelilingmu. Karena itu maafkanlah mereka, mohonkanlah ampun bagi mereka, dan bermusyawaratlah dengan mereka dalam urusan itu. Kemudian apabila kamu telah membulatkan tekad, maka bertawakkallah kepada Allah. Sesungguhnya Allah menyukai orangorang yang bertawakkal kepada-Nya.

Berdasarkan ayat diatas manusia diperintahkan untuk berlaku lemah lembut 
agar orang lain merasa nyaman bila berada disampingnya. Begitu juga dalam layanan yang mana pelanggan mempunyai banyak pilihan, bila pelaku lembaga keuangan syariah tidak mampu memberikan rasa aman dengan lemah lembutanya maka konsumen akan berpindah ke perusahaan lain. hasil penelitian nilai dimensi assurance sig- $\dagger$ sebesar 0.567> 0.05, menunjukkan bahwa variabel assurance tidak berpengaruh secara signifikan terhadap kepuasan anggota koperasi karyawan unit jasa keuangan syariah yayasan palapa nusantara.

\section{Pengaruh indikator Emphty Terhadap Kepuasan}

Lupiyoyadi (2008:182) menjelaskan empati sebagai usaha dari perusahaan untuk memberikan perhatian yang tulus dan bersifat pribadi yang diberikan kepada pelanggan dalam rangka memenihi keinginan pelanggan. Dimana suatu perusahaan diharapkan memiliki pengetahuan tentang pelanggan, memahami kebutuhan pelanggan secara spesifik, serta memiliki waktu pengoprasian yang nyaman. Hal ini merupakan wujud kepatuhan penyedia jasa terhadap perintah Allah Ta'alā untuk selalu peduli terhadap kondisi dan kebutuhan orang lain, sebagaimana firman-Nya dalam Qs. AnNahl ayat 16:90:

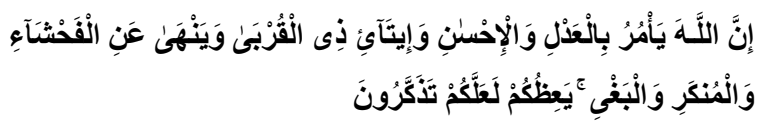

inna'l-Lāha ya'muru bi'l'ad-li wa'l-ihsāni wa-ītā-i żillqurbā wa-yanhā 'ani'l-fahsyāi wa'l-munkari wa'l-bagyi, ya'izukum la'allakum tażakkarūn.

Arinya:"Sesungguhnya Allah menyuruh (kamu) berlaku adil dan berbuat kebajikan, memberi kepada kaum kerabat, dan Allah melarang dari perbuatan keji, kemungkaran dan permusuhan. Dia memberi pengajaran kepadamu agar kamu dapat mengambil pelajaran."

Yaitu dalam sebuah lembaga jasa syariah harus senatiasa memberikan perhatian khusus terhadap masing-masing pelanggannya yang ditunjukkan dengan sikap komunikatif yang diiringi kepahaman tentang kebutuhan pelanggan namun hasil penelitian nilai sig- $\dagger$ Emphty sebesar 0,912 > 0.05, menunjukkan bahwa variabel emphty tidak berpengaruh secara signifikan terhadap kepuasan anggota koperasi karyawan unit jasa keuangan syariah yayasan palapa nusantara. Maka dari pihak palapa nusanara perlu meningkatkan pelayanan pada variabel-variabel yang menurut penilaian nasabah belum sesuai dengan yang diharapkan oleh nasabah.

Dari hasil analisis regresi menunjukkan bahwa sharia compliance, Tangibles, Reliability, Responsiveness. Assurance, dan Emphty secara simultan tidak berpengaruh terhadap kepuasan anggota, hal ini ditujukan dengan nilai sig-f 
sebesar 0,147> 0,05. Sedangkan R-square sebesar 0,301. Menunjukkan bahwa kepuasan nasabah dipengaruhi oleh variabel penerapan prinsip syariah, Tangibles, Reliability, Responsiveness. Assurance, dan Emphty

Dari hasi analisis regresi juga menunjukkan bahwa dimensi Reliability dan Responsiveness secara parsial berpengaruh signifikan terhadap kepuasan nasabah, hal ini ditunjukkan dengan nili sig- $\dagger$ yang lebih kecil dari 0,05. Sedangkan untuk dimensi penerapan prinsip syariah, Tangible, dan Assurance, dan Emphty secara parsial tidak berpengaruh signifikan terhadap kepuasan nasabah, hal ini ditunjukkan dengan nilai sig- $\dagger$ yang lebih besar dari 0,05. Ini sejalan dengan yang diungkapkan oleh Tjiptono (1999:128), bahwa meskipun fakta menunjukkan bahwa terjadi kegagalan penyampaian jasa, namun pelanggan bisa merasa puas. Hal ini disebabkan karena kriteria kepuasan tidak ditentukan oleh terpenuhinya semua harapan. Dengan demikian, maka kepuasan konsumen dapat tercapai meskipun tidak semua harapannya terpenuhi. Dari dimensi kualitas pelayanan yang singnifikan, dimensi responsiveness mempunyai pengaruh yang paling kuat terhadap kepuasan anggota unit jasa keuangan syariah yayasan palapa nusantara.

Beberapa dimensi kualitas layanan dalam penelitian ini tidak berpengaruh secara singnifikan terhadap kepuasan nasabah. Parningotan dkk (2008:87) menyampaikan, terkait dengan tisak konsisten jumlah dimensi, struktur faktor, maupun atribut yang dihasilkan lintas berbagai penelitian, dapat dipengaruhi oleh jasa yang diteliti dan budaya penelitian dilakukan. Dimensi kualitas jasa bergantung pada jasa tertentu. Carman (1990) dalam Parnigotan dll (2008:97) juga menyatakan bahwa paling sedikit sebagian konsumen bersifat context spesific mengenai dimensi yang digunakannya dalam menilai kulitas jasa. Ennew, Reed, dan Binks (1993) dalam Parningotan dkk (2008:108) juga menyarankan agar sifat jasa yang diukur juga dipertimbangkan. Dari dimensi kualitas pelayanan yang signifikan, dimensi Reliability mempunyai pengaruh paling kuat terhadap kepuasan anggota koperasi karyawan unit jasa keuangan yayasan palapa anusantara Surabaya.

\section{Simpulan}

Berdasarkan hasil
pembahasan yang dilakukan dalam
penelitian ini, maka dapat ditarik
kesimpulan sebagai berikut :Variabel
kualitas pelayanan dengan indikator:
Tangibles, Reliability, Responsiveness.

Assurance, dan Emphty nilai $\mathrm{F}$ hitung adalah sebesar 1.792 dengan nilai singnifikansi lebih besar dari 0,05 ( $a=5 \%)$, artinya tidak berpengaruh secara simultan terhadap anggota koperasi karyawan unit jasa kevangan syariah yayasan palapa nusantara. Sedangkan indikator dimensi 
Rohmati, et al/Jurnal Ekonomi Syariah Teori dan Terapan Vol. 3 No. 3 Maret 2016: 203-218; IMPLEMTASI KUALITAS PELAYANAN PENDEKATAN CARTER DAN PENGARUHNYA TERHADAP KEPUASAN UJKS KOPERASI KARYAWAN

reliability, dan responsiveness mempunyai pengaruh secara parsial terhadap kepuasan angota anggota koperasi karyawan unit jasa keuangan syariah yayasan palapa nusantara. Hal ini dapat dilihat dari dimensi Reliability menunjukkan bahwa Nilai sig- $†$ reliability sebesar 0,005 < 0.05 dan Nilai sig- $\dagger$ responsiveness sebesar $0,031<0.05$, sedangkan untuk dimensi layanan yang paling berpengaruh terhadap kepuasan anggota adalah Reliability sebesar 0,005 dikarenakan didalam kualitas pelayanan reliability salah satu faktor yaitu tersedianya area parkir yang luas, selain itu koperasi karyawan memberikan pelayanan sesuai yang dijanjikan.

Saran yang direkomendasikan setelah melakukan penelitian. Berdasarkan hasil analisis data yang telah dilakukan dalam penelitian ini dan sevai ketrbatasanketerbatasan yang telah diungkapkan sebelumya, maka saran yang diberikan oleh penulis adalah:

1. Bagi koperasi palapa nusantara hendaknya memperhatikan faktorfaktor variabel Kualitas Layanan yang tidak signifikan terutama pada indikator sharia compliance, reliability, tangibles, emphaty baik secara simultan maupun parsial agar dapat meningkatkan kualitas ayanan pada indikator tersebut I sehingga kedepan kepuasan anggota meningkat .
2. Penelitian selanjutnya diharpkan melakukan penelitian secara kualitatif untuk mendaptkan informasi secara wawancara mendalam kepada pihak terkait dan diharapkan menambahkan jumlah sampel dan variabel lain untuk mendapat hasil terbaik.

\section{DAFTAR PUSTAKA}

Al Qur'an dan Terjemahannya. 2005. Syamil Al Qur'an. Bandung: PT. Syaamil Cipta Media dan al Hadist.

Al Qur'an in Word Ver 1.3.1 oleh Muhammad Tufia

Arikunto, Suharsimi, 1998. Prosedur Penelitian, Suatu Pendekatan Praktek, Rineka Cipta, Jakarta.

Buchori, Nur S, 2009, Koperasi Syariah. Sidoarjo: Kelompok Masmedia Buana Pustaka.

Firman Sihol Parningotan,Lerbin R. Aritonang R.\& Novianta L.T. Hutagalung,2008.DIMENSI-DIMENSI

KUALITAS JASA PERBANKAN DI INDONESIA . Finance and Banking Journ al, Vol. 10 No. 2 Desember 2008 : 108 122.

Gujarati, Damodar., Lain, Sumarno, 1999. Ekonometrika Dasar, Erlangga,Jakarta.

---------Lain, Sumarno, 1997. Ekonometrika

Dasar, Erlangga, Jakarta -Lain, Sumarno, 2003. Ekonometrika Dasar, Erlangga, Jakarta 
Hines, William W.,Douglas C. Montgomery. 1990. Probabilita dan Statistik Dalam IImu Rekayasa dan Manajemen,Jakarta: UI Press.

Umar, Husein. 2000. Riset Pemasaran Dan

Perilaku Konsumen. Jakarta : PT

Gramedia Pustaka.

Imaroh, 2010. Perkembangan Koperasi

Syariahhttp://fossei.org/2013/01/menilik-

perkembangan koperasi syariah dan-

potensinya dalam perbaikan

kesejahteraan masyarakat, (diakses

pada 27 april 2015 ).

Kotler, Philip, 1995, Manajemen Pemasaran,

Jakarta: Salemba Empat.

dan Gary Amstrong. 2001. Prinsip-

prinsip Pemasaran Edisi Kedelapan.

Jakarta: Penerbit Erlangga.

-------. 2001 Prinsip-Prinsip Pemasaran Jilid 2.

Jakarta: Erlangga.

Lupiyoyadi, Rambat dan A. Hamdani. 2008.

Manajemen Pemasaran Jasa. Jakarta:

Salemba Empat.

Noraini, 2011 ,penelitian:"Pengaruh Kualitas

Layanan terhadap Kepuasan

Nasabah Bank BRI Syariah KCI

Surabaya

Othman, Owen (2002). Adopting and Measuring Customer Service Quality (SQ) in Islamic Banks: A Case Study in Kuwait Finance House, International Journal of Islamic Financial Services, Vol 3 N0. 1.
Parasuraman, et al. (1998). Service quality: A multiple item scale for measuring consumer perception of service quality.

(1994). Service quality : A multiple item scale for measuring consumer perception of service quality.

(1991). Service quality : A multiple item scale for measuring consumer perception of service quality.

Peraturan Mentri Nomor 16 Tahun 2015. 8 Oktober 2015. Lembaran Negara Republik Indonesia Tahun 2015 nomor 1495. Jakarta.

Singgih Santoso. 2002. SPSS Versi 11.5 Cetakan Kedua Jakarta: Gramedia

Sudarsono, Heri. 2004. Bank dan Lembaga Kevangan Syariah. Yogyakarta: Ekonisia.

Sugiyono, 2003, Cetakan Kelima,Statistika untuk penelitian dan aplikasinya dengan SPSS 10,0 For Windows, Bandung, Alfbeta. Tjiptono ,Fandi.(2001).Kualitas Jasa: Pengukuran, Keterbatasan dan Implikasi Manajerial, majalah Manajemen Usahawan Indonesia:Jakarta.

-,1999. Strategi Pemasaran. Edisi kedua Andi :Yogyakarta.

,1996. Strategi Pemasaran. Edisi

Peama Andi : Yogyakarta.

Transtrianingzah, Fia. 2006. Analisis Pengaruh Kualitas Layanan Terhadap Tingkat Kepuasan Nasabah pada Bank Muamalat Cabang Solo

Undang - Undang Republik Indonesia Nomor 25 Tahun 1992 Permodalan 
Rohmati, et al/Jurnal Ekonomi Syariah Teori dan Terapan Vol. 3 No. 3 Maret 2016: 203-218; IMPLEMTASI KUALITAS PELAYANAN PENDEKATAN CARTER DAN PENGARUHNYA TERHADAP KEPUASAN UJKS KOPERASI KARYAWAN

Koperasi. Lembaran Negara Republik Indonesia Nomor 25. Jakarta. 